\title{
Continuously sustained elimination of iodine deficiency: a quarter of a century success in the Islamic Republic of Iran
}

\author{
H. Delshad ${ }^{1} \cdot$ P. Mirmiran ${ }^{2} \cdot$ Z. Abdollahi $^{3} \cdot$ F. Salehi ${ }^{3} \cdot$ F. Azizi $^{4}$
}

Received: 29 August 2017 / Accepted: 22 January 2018 / Published online: 14 February 2018

(C) The Author(s) 2018. This article is an open access publication

\begin{abstract}
Background Iodine deficiency and related disorders were very common in Iran prior to 1996, when universal salt iodization (USI) was implemented and in 2000 Iran was declared iodine deficiency disorders (IDD) free. The aim of this study was to evaluate the adequacy of iodine intake by Iranian households in all 30 provinces of Iran, a quarter of a century after the intervention.

Methods A total of 18,000 school-aged children (8-10 years with mean $8.7 \pm 1$ year) were included in this study. Urine samples were collected from all children for measurement of urinary iodine excretion and 1800, 210 and 3000 salt samples were randomly collected from the family kitchen, production site of 73 salt factories and distribution circles of 30 provinces, respectively.

Results The median urinary iodine concentration (UIC) of participants was $161 \mu \mathrm{g} / \mathrm{L}$. The proportion of children with UIC of, $20-49,50-99$ and $\geq 100 \mu \mathrm{g} / \mathrm{L}$ were $10.3,15.9$ and $73.7 \%$, respectively. The mean ( \pm SD) and median salt iodine values were $28.2( \pm 12.6)$ and $31.7 \mathrm{ppm}$, at the production site, and $31.5( \pm 13.6)$ and $29.6 \mathrm{ppm}$ at the distribution circles, respectively. About $80 \%$ of factory salts had more than $20 \mathrm{ppm}$ iodine. $98 \%$ of households consumed iodized salt, $80 \%$ had appropriate salt storage, and $83 \%$ of the household salts contained $\geq 20 \mathrm{ppm}$.

Conclusions Based on the results of this study, Iranian populations are consuming adequate iodine. The well-maintained and monitored USI program has improved the dietary iodine intakes of the population, and the country has achieved all criteria of a well-controlled IDD program.
\end{abstract}

Keywords Iodine $\cdot$ Iodine deficiency $\cdot$ UIC $\cdot$ Iodized salt $\cdot$ Iran

\section{Introduction}

As an essential nutrient, iodine is required for the production of thyroid hormones [1]. Since the body does not make iodine, it relies on the diet for sufficient iodine intake. The main cause of iodine deficiency is low iodine content in the diet. Severe iodine deficiency has adverse effects on the mean intelligence quotient of the population [2], and iodine supplementation could increase the intelligent quotient in children affected by iodine deficiency [3]. Low iodine intake is the main cause of preventable mental retardation. Worldwide efforts by international agencies have resulted in achieving iodine sufficiency by the year 2005 [4-7], although many countries, even in industrialized ones, are

\section{H. Delshad \\ delshad1336@yahoo.com}

Extended author information available on the last page of the article still iodine deficient [8-12]. Universal salt iodization as a safe, cost-effective and sustainable strategy was recommended by the World Health Organization (WHO) and the United Nations Children's Fund (UNICEF) in 1994 to ensure sufficient intake of iodine by all individuals. Over the last century, considerable efforts worldwide have been paid to control this nutritional problem, but still many countries in the world are iodine deficient. Globally, $29.8 \%$ of schoolage children (246 million) are estimated to have insufficient iodine intake. During the past decade, the number of iodinedeficient countries has decreased from 54 to 30 while iodinesufficient ones have increased from 67 to 112; the number of countries with excessive iodine intake has increased from 5 to 10 . Although worldwide $90 \%$ of households consume adequately iodized salt, consumption is still below $50 \%$ in 39 countries [13-15].

In Iran, iodine deficiency was common in most of its regions, with moderate to severe endemic goiter, cretinism, 
retarded brain and mental development being common in many parts of the country $[16,17]$. Deficiency in iodine nutrition, despite being recognized in Iran since 1968 [18], was not categorized as a public health problem until 1980 . The National Iranian Committee for Control of IDD was formed in 1989 and since then USI has resulted in sustainable preventive programs of IDDs, leading to great success in IDD control and elimination. In 2000, IR Iran was recognized as an iodine-sufficient country by the WHO Eastern Mediterranean Regional Office [19].

The sustainability of iodine sufficiency is a major concern after achieving the criteria of iodine repletion [20,21]. A false sense of iodine sufficiency of the population is the major cause of failure in iodine deficiency elimination programs [22]. The National Iranian Committee for Control of IDD has scheduled control programs every 5-6 years to evaluate the sustainability of the program. This study aimed at confirming the updated data on iodine nutrition among schoolchildren in the I.R. Iran.

\section{Materials and methods}

A cross-sectional cluster survey among schoolchildren aged 8-10 years was conducted between October 2013 and February 2014, using recommended standard methods and approaches. Urinary iodine levels and the amount of iodine content of salt were measured among schoolchildren, at factories, distribution sites and households. The survey protocol was reviewed and approved by the ethics committee of the Research Institute of Endocrine Sciences (RIES) affiliated to Shahid Beheshti University of Medical Sciences.

\section{Subjects and sampling}

\section{Urinary iodine concentration}

For urinary iodine determination, 600 subjects, an equal number of girls and boys, i.e., 30 clusters of schoolchildren $(n=20$ each $)$ aged 8-10 years were selected in each province. Written informed consent was received from the parents of participants before the study. Thirty primary schools were selected proportionate to population size [23] in each province from the national database maintained by the Ministry of Education; and 20 children, aged 8-10 years, were sampled at random in each school. From 30 provinces of the country, urine samples of overall 18,000 schoolchildren (equal numbers of rural and urban) were obtained. These samples were transferred in screwtop plastic bottles on ice to the RIES laboratory and kept frozen at $-20{ }^{\circ} \mathrm{C}$ until the time of iodine measurement at the end of the study. All participants were requested to bring a salt sample from their house, with the brand name written on it.

From salt factories, five samples from different parts of each of the 73 iodized salt producing factories and 100 samples from distribution sites in each province were collected and sent to the food and drug control laboratory of the health center in each province. At the measurement site, a small portion of the salt was tested with a rapid test kit (MBI Kits, India). Salt envelopes were marked with the subjects' unique codes and samples were delivered to the laboratory of the Research Institute for Endocrine Sciences for measuring the iodine content by titration. Quantitative iodine measurement was performed at the center. Samples of iodized salt for household use (1800 samples from all provinces) were collected for quality and quantity control, and the content of household salt was measured in the field, using rapid testing kits [24]. Approximately, $10 \%$ of salt samples were randomly selected and transferred to the laboratory for food and drug control of the health center in each province for iodometric titration.

\section{Laboratory measurement}

Three trained technicians measured the iodine concentration of all urine samples using the acid digestion method at the RIES laboratory, [25, 26]. The intra-assay coefficient of variation (CV) of the UIC measurement method for concentrations of $3.5,15$ and $38 \mu \mathrm{g} / \mathrm{L}$ was $11.2,8.2$ and $9.4 \%$, respectively, and the inter-assay $\mathrm{CV}$ values for these concentrations were $12.5,8.9$ and $10.3 \%$, respectively. Iodometric titration assay was used for quantitative salt iodine measurements [27] and values are shown in parts per million (ppm). The reaction mechanism for iodometric titration includes two steps. (1) Liberation of free iodine from salt by the addition of $\mathrm{H}_{2} \mathrm{SO}_{4}$ liberates free iodine from the iodate in the salt sample. Then, excess $\mathrm{KI}$ is added to help solubilize the free iodine, which is quite insoluble in pure water under normal conditions. (2) Titration of free iodine with thiosulfate. Free iodine is consumed by sodium thiosulfate in the titration step. The amount of thiosulfate used is proportional to the amount of free iodine liberated from the salt. Starch is added as an external (indirect) indicator of this reaction and reacts with free iodine to produce a blue color. When added toward the end of the titration, i.e., when only a trace amount of free iodine is left, the loss of blue color, or end point, which occurs with further filtration, indicates that all remaining free iodine has been consumed by thiosulfate. This titration method has been standardized by RIES and approved by the Ministry of Health and Medical Education (MHME) for uniform measurement of salt iodine in the laboratories for food and drug control of the health center of each province. 


\section{Definitions}

Iodine deficiency was considered as a median urinary iodine concentration (UIC) $<100 \mu \mathrm{g} / \mathrm{L}$. Median UICs of 50-99, $20-49$ and $<20 \mu \mathrm{g} / \mathrm{L}$ were considered mild, moderate and severe iodine deficiency, respectively, while median UICs of 100-199, 200-299 and $\geq 300 \mu \mathrm{g} / \mathrm{L}$ were considered adequate, more than adequate and excessive, respectively [28]. For salts, iodine levels of $<20,20-40$ and $>40 \mathrm{ppm}$ were considered inadequate, adequate and excessive, respectively.

\section{Statistical analyses}

Percentage, arithmetic mean, median and standard deviation were used to present the data. Appropriate tests of significance $\left(\chi^{2}\right.$, Student's test, analysis of variance (ANOVA) and Mann-Whitney $U$ tests) were applied wherever necessary. Correlations between continuous numerical variables were assessed by Spearman's rank and Pearson coefficients. SPSS 9.05 software package (SPSS, Inc., Chicago, IL) was used for the statistical analysis and $p<0.05$ was considered to be significant.

\section{Results}

A total of 18,000 school-aged children (8-10 years with mean $8.7 \pm 1$ year) were included in this study.

\section{Urinary iodine concentration}

The median UIC of schoolchildren was $161 \mu \mathrm{g} / \mathrm{L}$. Figure 1 shows the median UICs of all provinces in bar graphs compared to the previous study [29]; 10.3, 15.9 and $73.7 \%$ of children had urinary iodine excretion levels of 20-49, 50-99 and $>100 \mu \mathrm{g} / \mathrm{L}$, respectively. There was no significant difference in UICs between boys and girls or between rural and urban areas (Table 1). All provinces had median UIC $>100 \mu \mathrm{g} / \mathrm{L}$.

\section{Salt iodine at the production level}

The mean $( \pm \mathrm{SD})$ and median salt iodine at the production level were $28.2( \pm 12.6)$ and $31.7 \mathrm{ppm}$, respectively. Iodine levels of $<20,20-40$ and $>40 \mathrm{ppm}$ were observed in 9,71 and $20 \%$ of the samples, respectively. About $80 \%$ of factory salts had $>20 \mu \mathrm{g} / \mathrm{L}$ iodine.

\section{Salt iodine at the distribution level}

The mean $( \pm \mathrm{SD})$ and median of iodine level concentrations were 31.5 ( \pm 13.6$)$ and $29.6 \mathrm{ppm}$, respectively, at the distribution level. Iodine levels of $<20,20-40$ and
$>40 \mathrm{ppm}$ were observed in 11, 59 and $30 \%$ of the samples, respectively.

\section{Salt iodine at the household level}

Ninety-eight percent of households consumed iodinated salt, of which $82 \%$ was crystallized iodized salt. Fifty-eight percent of households had appropriate salt storage. Quantitative assays of household salt samples showed that the median iodine content was $30 \mathrm{ppm}$. Iodine levels $<20$, $20-40$ and $>40$ ppm were observed in 17,63 and $20 \%$ of household salts, respectively. An iodine content $\geq 40 \mathrm{ppm}$ was more frequently found in the salt samples collected in provinces where the median UIC values in schoolchildren were more than $200 \mu \mathrm{g} / \mathrm{L}$ (76 VS 24\%). Figure 2 depicts the distribution of salt iodine content at different levels in this study.

\section{Discussion}

The prevalence of goiter has decreased gradually over the last 25 years in Iran. According to our previous national study [29], weighted TGR was 5.7\% and all subjects had low-grade goiter, and median urinary iodine concentration (UIC) was over $100 \mu \mathrm{g} / \mathrm{dl}$, indicating that the subjects had adequate iodine intake. The present national survey, which was conducted in 2013-2014, indicated sustainable elimination of IDDs and favorable urinary iodine values in schoolaged children of 30 provinces of Iran (Table 1). Since clinical evaluation of low-grade goiter has less validity, in this study urinary iodine rather than goiter prevalence was used as the principal indicator of iodine status.

Median urinary iodine concentration of schoolchildren in the current survey was $161 \mu \mathrm{g} / \mathrm{L}$. This value was $205 \mu \mathrm{g} / \mathrm{L}$ in $1996,165 \mu \mathrm{g} / \mathrm{L}$ in 2001 and $140 \mu \mathrm{g} / \mathrm{L}$ in 2007 (Table 2). In 1996, 2 years after mandatory salt iodization in Iran, the median UIC values of schoolchildren were higher than the WHO/UNICEF/ICCIDD optimal levels in many provinces of the country, and in 2001, after 7 years of national salt iodization, despite a change in salt iodine content, the median UIC of Iranian schoolchildren was optimal. The decline in median UIC values from 1996 to 2013 in our study may have been due to changes in dietary habits, particularly in younger people or some other environmental factors. Iodized oil injection during earlier years of salt iodization may also have played a key role in the above optimal levels of median UIC of schoolchildren in 1996. Such a downward trend was also observed between the National Health and Nutrition Examination Surveys 1 and 3 in the USA; however, it finally stabilized at adequate UIC levels in the next survey [30]. This change is particularly important during pregnancy and lactation when low iodine intakes could be accompanied by 
Fig. 1 Comparison of median UICs in all provinces of Iran in 2007 and 2014

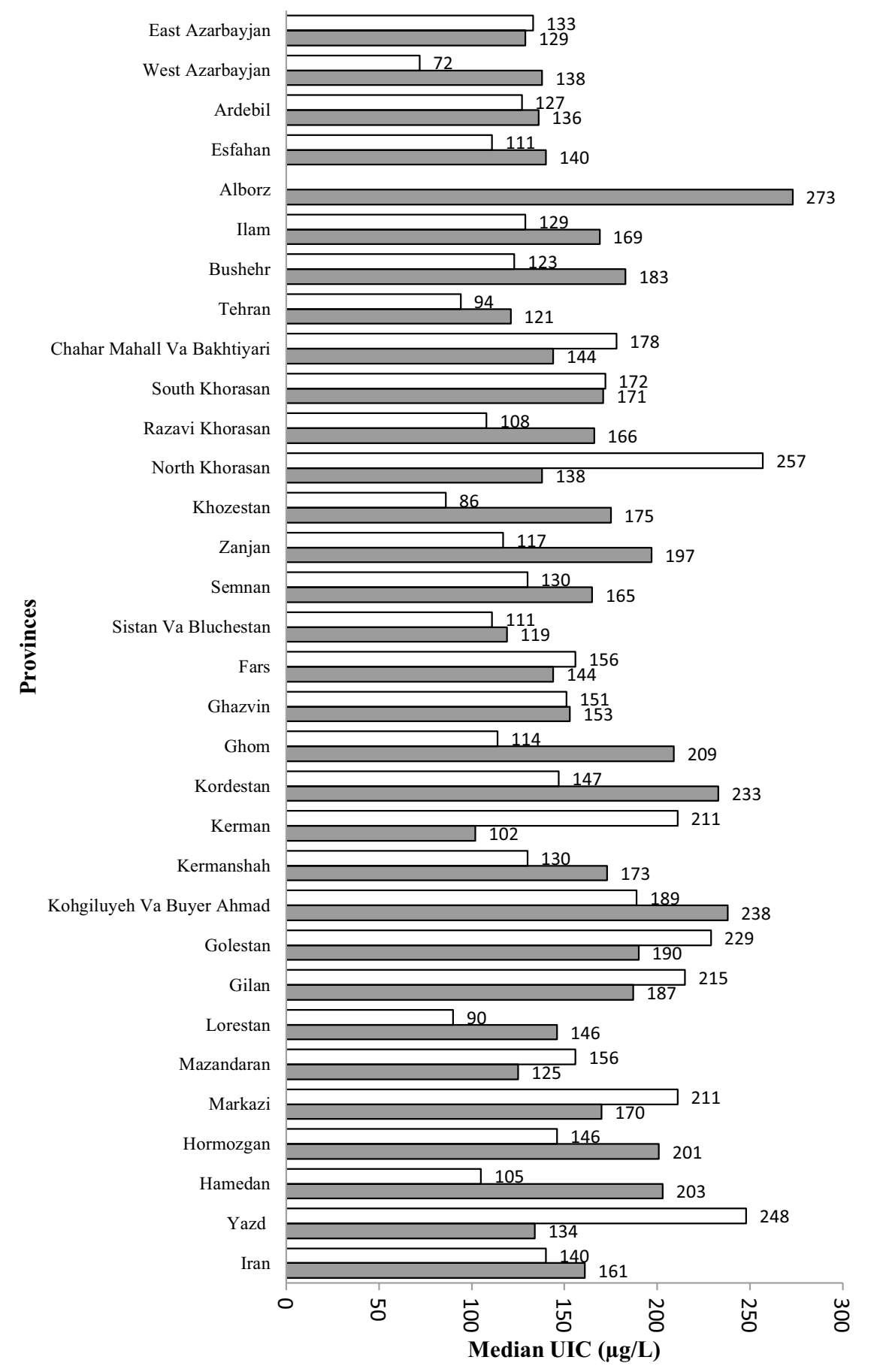

$\square 2007$

$\square 2014$
Table 1 Median urinary iodine content $($ UIC $=\mu \mathrm{g} / \mathrm{L})$ among schoolchildren aged $8-10$ years of 30 provinces of Iran $(n=18,000)$

\begin{tabular}{lccc}
\hline & Girls & Boys & Total \\
\hline Urban & $163^{\mathrm{a}}$ & 161 & 164 \\
Rural & 153 & 163 & 158 \\
Total & 158 & 162 & 161 \\
\hline
\end{tabular}

${ }^{\mathrm{a}} \mu \mathrm{g} / \mathrm{L}$ adverse outcomes in vulnerable populations such as neonates, infants and young children [31].

Since 1996, the mean $( \pm$ SD) and median salt iodine at the production level have not changed significantly, as current values are $28.2( \pm 12.6)$ and $31.7 \mathrm{ppm}$, respectively, while corresponding values in 1996 for 278 factory salt samples were 33.8 ( \pm 13.2) and $33.9 \mathrm{ppm}$, in 2001 for 297 samples $33.2( \pm 13.4)$ and $32.8 \mathrm{ppm}$, and for 280 samples in 2007, $23.2( \pm 13.8)$ and $34.7 \mathrm{ppm}$, respectively [32-34]. 


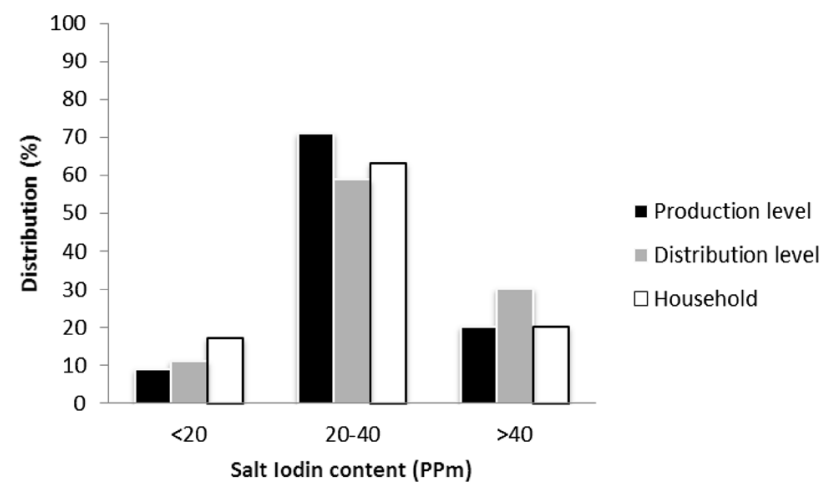

Fig. 2 Distribution (\%) of salt iodine content (ppm) at production, distribution and household levels (
Table 2 Changes in median urinary iodine (MUI) and total goiter rate (TGR) in schoolaged children between 1989 and 2013

\begin{tabular}{lll}
\hline Year & MUI $(\mu \mathrm{g} / \mathrm{L})$ & TGR $^{\mathrm{a}}(\%)$ \\
\hline 1989 & $12-82$ & 68.0 \\
1996 & 205 & 54.0 \\
2001 & 165 & 9.8 \\
2007 & 140 & 5.7 \\
2013 & 161 & Not done \\
\hline
\end{tabular}

${ }^{\mathrm{a}}$ Goiter was assessed by palpation
In 2013, frequency distributions of factory salts with iodine contents of $<20,20-40$ and $>40$ ppm were 9,71 and $20 \%$ of samples, whereas in 2007, 2001 and 1996 it was 12, 70 and $18 \%, 17.2,54.5$ and $28.3 \%$, and $15.8,54.7$, and $29.5 \%$, respectively. The median iodine contents of household salt sample were $30 \mathrm{ppm}$ in 2013 and 2007 and $32.8 \mathrm{ppm}$ in both 2001 and 1996. The frequency distributions of household table salts showed no significant differences during the last four periods. The iodine contents of $<20,20-40$ and $>40$ ppm were 27,53 and $20 \%$ in $2007 ; 8.3,71.7$ and $20.0 \%$ in 2001; and 7.8, 71.9 and $20.3 \%$ in 1996 , respectively.

Iodine-deficient soil is the major cause of iodine deficiency. Lapses in the monitoring programs and inadequate iodine supplies to the population at risk are the main factors for recurrence of iodine deficiency in a community. Evidence shows IDD relapse in some countries that had previously been successful in controlling IDD; in several countries with well-controlled IDD by USI, control programs have faltered and IDD recurred [35-40]. In some industrialized countries such as Australia and New Zealand, previously thought to be iodine sufficient, IDDs have also relapsed [37, 38]. A study by Zimmermann et al., in an area of endemic goiter in Morocco, showed that changes in thyroid function have occurred after sudden interruption of USI [39]. A survey by Vanderpump indicates that the U.K. population is iodine deficient. In this study, $69 \%$ of 810 British girls, aged $14-15$ years, had median UIC $<100 \mu \mathrm{g} / \mathrm{L}$; which is consistent with iodine deficiency according to WHO standards. In addition, $18 \%$ had UIC levels below $50 \mu \mathrm{g} / \mathrm{L}$ [40]. These data indicate that IDD control programs are fragile and depend on a strong, long-term commitment from governments, donors, consumers and the salt industry. Monitoring of the indicators is a vital element of an effective and sustained program for the control and elimination of iodine deficiency disorders [41]. An IDD control program is defined by the median urinary iodine concentration (UIC) in school-aged children. If the median UIC is adequate in this group, it is usually assumed iodine intakes of iodized salt are also adequate in the remaining population; therefore based on the results of this study, Iranian populations are consuming adequate iodine, but because iodine requirements sharply increase during pregnancy, universal salt iodization cannot cover this vulnerable group's iodine needs. Many recent studies have shown that pregnant and lactating women are iodine deficient not only in iodine-deficient regions, but also in iodine-sufficient areas and need at least $150 \mu \mathrm{g}$ iodine supplementation per day during pregnancy and lactation [42-45]. In another study conducted on 100 pregnant and 84 lactating women, we also found a suboptimal iodine nutritional status in these women [46]. Despite optimal iodine nutrition in Iranian school-aged children, further efforts should be made to understand the importance of, and to guarantee, an adequate iodine intake in pregnant and lactating women.

\section{Conclusion}

A well-organized USI program has ultimately resulted in optimization of UIC and decreased the prevalence of goiter 18 years after USI. The median urinary iodine of schoolchildren was adequate in this survey, as those reported in 1996, 2001 and 2007. According to these criteria, the I.R. of Iran has achieved and maintained a sustainable IDD control program since 1996. The implementation of a sustainable and well-monitored IDD control program needs many effective programmatic steps, in particular its integration into the health network; furthermore, it may also require mandatory iodized salt consumption in certain situations.

Acknowledgements The authors wish to thank the participants for their co-operation in this study. The authors also wish to acknowledge Ms. Niloofar Shiva for critical editing of English grammar and syntax of the manuscript.

Author contributions HD: designing and writing of the main proposal and final report. PM: co-operation in the field. ZA: co-operation in the field. FS: co-operation in the field. FA: designing and supervision of the different steps of the project. 


\section{Compliance with ethical standards}

Conflict of interest The authors declare that they have no conflict of interest.

Ethical approval The local ethics committee approved the study protocol.

Informed consent Informed consent was obtained from all individual participants included in the study.

Open Access This article is distributed under the terms of the Creative Commons Attribution 4.0 International License (http://creativeco mmons.org/licenses/by/4.0/), which permits unrestricted use, distribution, and reproduction in any medium, provided you give appropriate credit to the original author(s) and the source, provide a link to the Creative Commons license, and indicate if changes were made.

\section{References}

1. Zimmerman MB (2009) Iodine deficiency. Endocr Rev 30:376-408

2. Bleichrodt N, Born MP (1994) A meta-analysis of research on iodine and its relationship to cognitive development. The damaged brain of iodine deficiency. Cognizant Communication Corporation, New York, pp 195-200

3. Salarkia N, Mirmiran P, Azizi F (2004) Timing of the effect of iodine supplementation on intelligence quotients of schoolchildren. Int J Endocrinol Metab 2:95-102

4. Hetzel BS (1987) Progress in the prevention and control of iodine-deficiency disorders. Lancet 2:266-271

5. De Benoist B, McLean E, Andersson M, Rogers L (2008) Iodine deficiency in 2007: global progress since 2003. Food Nutr Bull. 29:195-202

6. Andersson M, Takkouche B, Ines Egli I (2005) Current global iodine status and progress over the last decade towards the elimination of iodine deficiency. Bull World Health Organ $83: 518-525$

7. World Health Organization (1998) Elimination of iodine deficiency disorders in South-East Asia. Report of an expert consultative meeting. WHO, Nonthaburi, 2007

8. Dunn JT (1998) What is happening to our iodine? J Clin Endocrinol Metab 83:3398-3400

9. Delange F, de Benoist B, Pretell E, Dunn JT (2001) Iodine deficiency in the world: where do we stand at the turn of the century? Thyroid 11:437-447

10. Vitti P, Delange F, Pinchera A, Zimmermann M, Dunn JT (2003) Europe is iodine deficient. Lancet 361:1226

11. De Benoist B, Andersson M, Takkouche B, Egli I (2003) Prevalence of iodine deficiency worldwide. Lancet 362:1859-1860

12. UNICEF (2008) Sustainable elimination of iodine deficiency. UNICEF, New York

13. Zimmermann MB, Andersson M (2012) Update on iodine status world wide. Curr Opin Endocrinol Diabetes Obes 19(5):382-387

14. Zimmermann MB (2013) Iodine deficiency and excess in children: worldwide status in 2013. Endocr Pract. 19(5):839-846

15. Pearce EN, Andersson M, Zimmermann MB (2013) Global iodine nutrition: where do we stand in 2013? Thyroid 23(5):523-528

16. Azizi F, Sarshar A, Nafarabadi M, Ghazi A, Kimiagar M, Noohi S, Rahbar N, Bahrami A, Kalantri (1993) Impairment of neuromotor and cognitive development in iodine deficient schoolchildren with normal physical growth. Acta Endocrinol (Copenh) 129:501-504

17. Azizi F, Kalani H, Kimiagar M, Ghazi A, Sarshar A, Nafarabadi M, Rahbar N, Noohi S, Mohajer M, Yassai M (1995) Physical, neuromotor and intellectual impairment of noncretinous schoolchildren with iodine deficiency. Int J Vitam Nutr Res 65:199-205

18. Emami A, Shahbazi H, Sabzevari M, Gawam Z, Sarkissian N, Hamedi P (1969) Goiter in Iran. Am J Clin Nutr 22:1584-1588

19. World Health Organization (2000) Regional meeting for the promotion of iodized Salt in the Eastern Mediterranean, Middle East and North Africa: report of an Inter-Country meeting. WHO, Dubai

20. WHO/UNICEF/ICCIDD (1994) Indicators for assessing iodine deficiency disorders and their control through salt iodization. WHO, Geneva

21. Azizi F (2003) Salt iodization, monitoring, and evaluation (SIME): an effective replacement for universal salt iodization (USI). Int J Endocrinol Metab 2:46-47

22. Dunn JT (2000) Complacency: the most dangerous enemy in the war against iodine deficiency. Thyroid 10:681-683

23. Lwanga SK, Lemeshow S (1990) Sample size determination in health studies. WHO, Geneva

24. Narasinga Rao BS, Ranganathan S (1985) A simple field kit for testing iodine in salt. Food Nutr Bull 7:70-72

25. Sandell EB, Koltoff IM (1937) Micro determination of iodine by a catalytic method. Michrochem Acta 1:9-25

26. Dunn JT, Crutchfeld HE, Gutekunst R, Dunn AD (1993) Methods for measuring iodine in urine. ICCIDD, UNICEF, WHO (OMS), Wagenigen

27. WHO, UNICEF, ICCIDD (1994) Indicators for assessing iodine deficiency disorders and their control through salt iodization. WHO, Geneva

28. Sullivan KM, Robin H, Gorstein J, Cervinskas J (1995) Monitoring universal salt iodisation programs. UNICEF/PAMM/MI/ ICCIDD/WHO, Atlanta

29. Delshad Hossien, Amouzegar Atieh, Mirmiran Parvin, Mehran Ladan, Azizi Fereidoun (2012) Eighteen years of continuously sustained elimination of iodine deficiency in the Islamic Republic of Iran: the vitality of periodic monitoring. Thyroid 22:415-421

30. Caldwell KL, Jones R, Hollowell JG (2005) Urinary iodine concentration: United States National Health and Nutrition Examination Survey; 2001-2002. Thyroid 15:692-699

31. Stanbury JB (ed) (1994) The damaged brain of iodine deficiency. Cognizant Communication, New York

32. Azizi F, Kimiagar M, Nafarabadi M, Yassai M (1990) Current status of iodine deficiency in the Islamic Republic of Iran. EMR Health Serv J. 8:23-27

33. Azizi F, Sheikholeslam R, Hedayati M, Mirmiran P, Malekafzali H, Kimiagar M, Pajouhi M (2002) Sustainable control of iodine deficiency in Iran: beneficial results of the implementation of the mandatory law on salt iodization. J Endocrinol Invest 25:409-413

34. Azizi F, Mehran L, Sheikholeslam R, Ordookhani A, Naghavi M, Hedayati M (2008) Sustainability of a well-monitored salt iodization program in Iran: marked reduction in goiter prevalence and eventual normalization of urinary iodine concentrations without alteration in iodine content of salt. J Endocrinol Invest 31:422-431

35. Current IDD status database. International council for the control of iodine deficiency disorders website. www.iccidd.org. Accessed 12 Aug 2003

36. Markou KB, Georgopoulos NA, Makri M, Anastasiou E, Vlasopoulou B, Lazarou N, Veizis A, Sakellaropoulos G, Vagenakis AG (2001) Iodine deficiency in Azerbaijan after the discontinuation of an iodine prophylaxis program: reassessment of iodine intake and goiter prevalence in schoolchildren. Thyroid 11:1141-1146 
37. Li M, Ma G, Boyages SC, Eastman CJ (2001) Re-emergence of iodine deficiency in Australia. Asia Pac J ClinNutr 10:200-203

38. Thomson CD, Woodruffe S, Colls AJ, Joseph J, Doyle TC (2001) Urinary iodine and thyroid status of New Zealand residents. Eur J Clin Nutr 55:387-392

39. Zimmermann M, Wegmuller R, Zeder C, Torresani T, Chaouki N (2004) Rapid relapse of thyroid dysfunction and goiter in schoolage children after discontinuation of salt iodization. Am J Clin Nutr 79:642-645

40. Vanderpump M. (2011) UK population is iodine deficient. Presented at Society for Endocrinology BES, Birmingham, United Kingdom, April 11-14, 2011

41. WHO, UNICEF, ICCIDD (2001) Assessment of iodine deficiency disorders and monitoring their elimination, 2nd edn. WHO, Geneva

42. Krylova K, Bilek R, Kulicka J, Dejmek P, Bayer M, Kacerovsky M, Neumann D (2017) Urinary iodine concentrations in mothers and their term newborns in country with sufficient iodine supply. J Matern Fetal Neonatal Med 30(21):2633-2639

43. Leung AM, Pearce EN, Braverman LE (2011) Iodine nutrition in pregnancy and lactation. Endocrinol Metab Clin North Am 40:765-777

44. Gowachirapant S, Winichagoon P, Wyss L, Bennan Tong BJ, Melse-Boonstra A, Zimmermann MB (2009) Urinary iodine concentrations indicate iodine deficiency in pregnant Thai women but iodine sufficiency in their school-aged children. J Nutr 139:1169-1172

45. Andersen SL, Sørensen LK, Krejbjerg A, Møller M, Laurberg P (2013) Iodine deficiency in Danish pregnant women. Dan Med J 60:A4657

46. Nazeri P, Zarghani NH, Mirmiran P, Hedayati M, Mehrabi Y, Azizi F (2016) Iodine status in pregnant women, lactating mothers, and newborns in an area with more than two decades of successful iodine nutrition. Biol Trace Elem Res 172(1):79-85

\section{Affiliations}

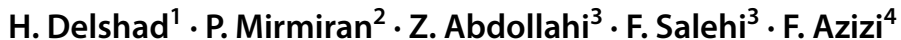

P. Mirmiran

mirmiran.m@endocrine.ac.ir

Z. Abdollahi

abdollahi_z@yahoo.com

F. Salehi

salehi46@yahoo.com

F. Azizi

azizi@endocrine.ac.ir
2 Nutrition Research Center, Research Institute for Endocrine Sciences, Shahid Beheshti University of Medical Sciences, Tehran, Islamic Republic of Iran

3 Ministry of Health and Medical Education, Tehran, Islamic Republic of Iran

4 Research Institute for Endocrine Sciences, Shahid Beheshti University of Medical Sciences, Tehran, Islamic Republic of Iran

1 Micronutrient Research Office, Research Institute for Endocrine Sciences, Shahid Beheshti University of Medical Sciences, 19395-4763 Tehran, Islamic Republic of Iran 